\title{
Translator's Gender and Language Features of the Tao Te Ching English Translations: A Next Step into the Translation from Individuation Perspective in Systemic Functional Linguistics
}

\author{
Xi Wang ${ }^{1 \& 2}$ \\ ${ }^{1}$ College of International Studies, Southwest University, Chongqing, China \\ ${ }^{2}$ Faculty of Arts and Social Sciences, University of Sydney, Sydney, Australia \\ Correspondence: Xi Wang, College of International Studies, Southwest University, Chongqing, China. E-mail: \\ chaoxi881@sina.com
}

$\begin{array}{lc}\text { Received: April 5, } 2015 & \text { Accepted: May 5, } 2015 \quad \text { Online Published: May 30, } 2015 \\ \text { doi:10.5539/ijel.v5n3p96 } & \text { URL: http://dx.doi.org/10.5539/ijel.v5n3p96 }\end{array}$

This study was supported by State Scholarship Fund under the Grant No. 201406990036.

\begin{abstract}
Systemic functional approaches to translation studies have focused on the parameters of translation equivalence and shift within the hierarchy of realisation. However, translations from the perspective of individuation focus on language users, i.e., the author, translator and reader, involving ideological issues, showing tendentiously the genre, register and free options in a language in accordance with individual factors such as class, gender, age, race etc. to the language user. The present paper looks into one of the most significant individual factors-gender of the translator-in the English translations and re-translations of the Tao Te Ching as a next step into the model of individuation translation by using both qualitative and quantitative methods. The result shows that women translators' re-individuations are more spoken, while men's are more written in style, reflecting in three aspect: the choice of words, the choice of syntactic patterns and the choice of mood.
\end{abstract}

Keywords: Individuation, translation, the Tao Te Ching, gender, SFL

\section{Introduction}

Tao Te Ching, as the most frequently translated Chinese classic only next to the Bible, has obtained a widespread and diversified Western audience, appealing to readers on a variety of levels. There are over 130 English translations and re-translations of the Tao Te Ching (Xin, 2008, p. 17), which are classified according to time into three intensified translation periods: The first period (1868-1905), the second period (1934-1963), and the third period (1972-2004). In the late1960s, Women's Liberation Movement resulted in a more gender-emphasized society, where "social gender" was unprecedentedly focused on. The first woman involved English translation of the Tao Te Ching was published in 1972 by Gia-fu Feng \& Jane English, after which there were several versions translated by women translators on their own, for example, Ellen Marie Chen (1989), Ursula K. Le Guin (1997), Lee Sun Chen Org (2000) and Chao-Hsiu Chen (2004). The present paper will explore whether translators' gender will affect their choices of language in translations by using the hierarchy of individuation in systemic functional linguistics.

\section{Translation from the Perspective of Individuation in SFL}

Individuation is a relatively new concept in SFL, proposed first by Matthiessen (2003), borrowing the term from Bernstein (2000, p. 158) in his studies of language education, and then extended by Martin (2006, 2008a, 2008b, 2009). This theoretical parameter has taken on an identity perspective revealed by ideology, especially involving the issue how individuals employ language resources in culture. Halliday, in 1964, has elaborated language user and language use by locating them in two different levels, and distinguished dialectal, registerial and codal. Matthiessen (2007, p. 539) followed Halliday's (1964) view, considering coding orientation, or codal variation as affiliating to the cline of instantiation, located between dialectic variation and registerial variation, and merged individual with instance, regarding repertoire as the set of "register" extracted by individual "meaner" from the meaning potential of speech fellowship (i.e., reservoir). In comparison, Martin (2006, p. 276) views 
individuation as the relationship between system and individual, which is an independent complimentary hierarchy alongside realisation and instantiation, treating the three (i.e., realisation, instantiation and individuation) hierarchical relations as the theoretical resources of language research (Martin \& Wang, 2008). Martin (1992, p. 495) associated coding orientation with ideology, and located it between reservoir and repertoire. Inherited from Bernstein's (2000) point of view, Martin illustrated that individuation has to do with the relationship between the reservoir of meanings in a culture and the repertoire a given individual can mobilize. It is a cline from the collective to the individual, examining the social attributes of an individual from the systemic and functional perspective, such as ideology, intersubjectivity, identity and power, revealing the meaning potential of a given individual or community (Wang, 2011). Reservoir and repertoire interact with each other, locating at the two poles of the cline, where in between lies system, coding orientation, personality type and individual from top to bottom in turn. Individuation deals with classification and negotiation via two opposing paths - affiliation and allocation (Martin, 2009, p. 565).

Systemic functional approaches to translation studies have focused on the parameters of translation equivalence and translation shift. According to the hierarchy of individuation, Wang \& Yang (2015) proposed a translation model from the perspective of individuation, focusing on language users (i.e., the author, translator and reader), viewing translation activities as processes of shunting back to the source language (SL) reservoir through the de-individuation of the source text (ST) via alignment with the source language author, re-individuating it into the target text (TT) through allocation and at the same time aligning with the target language reader through affiliation (see Figure 1). They also took the English translations of the Tao Te Ching, an ancient Chinese philosophical classic by Lao Tzu 2500 years ago, as a case study. Translation from the perspective of individuation involves ideological issues, the system which can tendentiously show language users the genre, register and free options in a language in accordance with individual factors such as class, gender, age, race etc. The ideology has changed when the repertoire is opened anew by translators, where they will consider more or less the value of the SL or TL community, and then re-individuate according to the interests of translators themselves. The present paper will focus on one of the most important individual factors - the translator's gender-again in the English translations of the Tao Te Ching.

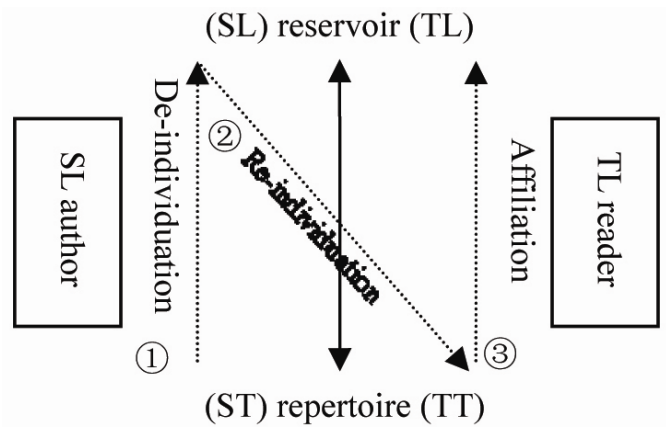

Figure 1. Process of individuation translation (Wang \& Yang, 2015)

\section{Translator's Gender and Language Features}

We selected eight different English translations, including one man and woman's cooperated translation (Feng \& English, 1972), three women's translations (Chen, 1989; Guin, 1997; Chen, 2004), and four men's translations (He et al., 1985; Wing, 1986; Mair, 1990; Gu, 1995), to compare and analyze whether there are differences between translations by men and women translators. Three aspects are examined: the choice of words, choice of syntactic patterns and choice of mood.

\subsection{Choice of Words}

Men and women translators may diverge in the choice of words when translating. For example:

Example 1: 故常光欲, 以观其妙。(Chapter 1)

Chen (1989): In order to observe (kuan) the hidden mystery (miao); Always (ch'ang) with desire (yu-yü)

Guin (1997): So the unwanting soul sees what's hidden

Chen (2004): Observe the mysteries of the Tao without longing 
Feng \& English (1972): Ever desireless, one can see the mystery.

He et al. (1985): Therefore, the subtleties of Tao are always apprehended through their formlessness

Wing (1986): Thus, without expectation/One will always perceive the subtlety;

Mair (1990): Always be without desire in order to observe its wondrous subtleties

$\mathrm{Gu}$ (1995): Hence one should gain an insight into the beginning of the Tao by constantly observing the Nothingness

In re-individuating “妙 (miao)", women translators choose "hidden” and "mystery", which are vivid descriptions, getting an impression of something covered and mysterious (Zheng, 2011). While men translators choose to use "subtlety(ties)" and "insight", both abstract nouns which are vague and general.

Example 2: 故能长先生。(Chapter 7)

Chen (1989): Therefore they last long.

Guin (1997): So they can go on and on.

Chen (2004): therefore they can live for ever.

Feng \& English (1972): So ever living.

He et al. (1985): And for this reason they obtain longevity.

Mair (1990): Therefore, They can be long-lived.

Wing (1986): For that reason they can exist eternally.

$\mathrm{Gu}$ (1995): Thus they enjoy an eternal life.

In re-individuating “长生 (chang sheng: long live)", women translators choose verbal groups like "ever living" "last long", "go on and on" "live for ever", whereas men, except Wing (1986), adopted a nominal approach such as "longevity" "long-lived" "eternal life".

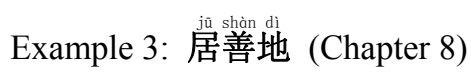

Chen (1989): (Such a person's) dwelling is the good earth

Guin (1997): For a house, the good thing is level ground.

Chen (2004): It settles only in quiet locations.

Feng \& English (1972): In dwelling, be close to the land.

He et al. (1985): In his dwelling he is at ease with lowness

Wing (1986): The value in a dwelling is location.

Mair (1990): The quality of an abode is in its location

$\mathrm{Gu}$ (1995): A man of perfect goodness chooses a low place to dwell as water

For “居 (ju: settle)", women translators re-individuate it as nouns like "dwelling" "house" and verbs like "settle", which are relatively spoken, while men translator Mair (1990) used the relatively written style of vocabulary "abode" which is rarely used in everyday English (Zheng 2011). For "善 (shan: good)", women choose adjectives like "good" "good thing" and "quiet", while Wing (1986) and Mair (1990) use abstract nouns like "value" "quality" and "goodness". For "地 (di: ground)", women choose again to use spoken style "land" "earth" "ground", except Chen (2004), whereas Wing (1986) and Mair (1990) re-individuate it as the written one "location", and He et al. (1985) and Gu (1995) adopt a free translation strategy by using "lowness" and "low place...as water".

Example 4: 其事好还。(Chapter 30)

Chen (1989): Such affairs have a way of returning (huan)

Guin (1997): that tactic backfires

Chen (2004): the others will return with the force of an army. 
Feng \& English (1972): For this would only cause resistance.

He et al. (1985): The use of force will soon incur requital.

Wing (1986): Such matters tend to recoil.

Mair (1990): Such a course is likely to boomerang.

$\mathrm{Gu}$ (1995): Military actions usually invite retaliatory aftermath

When translating “还 (huan: return)", women translators re-individuate it as relatively spoken words like "returning (huan)" "backfires" "return" and "resistance", while men chose to use more written ones like "requital" "recoil" "boomerang" and "retaliatory".

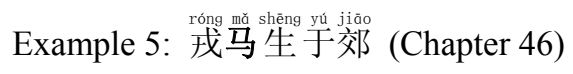

Chen (1989): War horses give birth at the borders

Guin (1997): they breed warhorses on the common

Chen (2004): war horses appear outside the city

Feng \& English (1972): War horses are bred outside the city

He et al. (1985): even mares with foal have to be used in battle

Wing (1986): War-horses are raised in the suburbs.

Mair (1990): war-horses breed in the suburbs.

$\mathrm{Gu}$ (1995): Even pregnant mares are taken over for wars.

In translating “马(ma: horse)”, women translators all choose "horses", whereas He et al. (1985) and Gu (1995) take into consideration the context and emphasized the female gender of the horses by using "mares" and "pregnant mares". This is probably because the female gender is unmarked to women translators while marked to men translators, and thus prominent in men's translations.

Example 6: 民丝之饥 (Chapter 75)

Chen (1989): People are hungry

Guin (1997): people are starving

Chen (2004): The people are hungry

Feng \& English (1972): Why are the people starving?

He et al. (1985): The people suffer from famine

Wing (1986): People are hungry.

Mair (1990): Human hunger

$\mathrm{Gu}$ (1995): The hunger on the part of the people

In re-individuating “饥”, women used adjective and verbs like "starving” and "hungry", whereas men chose to use nouns like "famine" and "hunger", except Wing (1986).

For further proof, the concept of "lexical density" and "grammatical intricacy" are used, where in Hallidayan (1985) sense, lexical density is the number of content words per clause, while grammatical intricacy is the number of clauses per clause complex. Spoken texts and written texts are complex in different ways, the former is said to have higher grammatical intricacy and lower lexical density, whereas the latter is opposite, higher lexical density and lower grammatical intricacy. That is because written texts are more inclined to use nominalisation, and the spoken texts are more dynamic grammatically. Table 1 shows the lexical density and grammatical intricacy of the ST and each English translations listed above: 
Table 1. Lexical density and grammatical intricacy of the ST and each English versions for example 1-6

\begin{tabular}{|c|c|c|c|c|c|c|c|}
\hline Clause & $\begin{array}{l}\text { 故常无欲, } \\
\text { 以观其妙。 }\end{array}$ & 故能长生 & 居善地 & 其事好还 & 戎马生于郊 & \multicolumn{2}{|l|}{ 民之饥 } \\
\hline & \multirow{2}{*}{\multicolumn{6}{|c|}{ Lexical Density }} & Grammatical \\
\hline & & & & & & & Intricacy \\
\hline ST & 1.5 & 1 & 3 & 3 & 3 & 2 & 1 \\
\hline Chen (1989) & 2 & 2 & 3 & 4 & 5 & 2 & 1 \\
\hline Guin (1997) & 2 & 2 & 5 & 2 & 3 & 2 & 1 \\
\hline Chen (2004) & 2 & 2 & 3 & 4 & 4 & 2 & 1 \\
\hline Means $(\mathrm{F})$ & 2 & 2 & 3.67 & 3.33 & 4 & 2 & 1 \\
\hline He et al. (1985) & 2 & 4 & 3 & 5 & 5 & 3 & 1 \\
\hline Wing (1986) & 1.5 & 3 & 3 & 3 & 3 & 2 & 1 \\
\hline Mair (1990) & 2 & 2 & 3 & 2 & 3 & 2 & 1 \\
\hline Gu (1995) & 3.5 & 4 & 8 & 5 & 4 & 3 & 1 \\
\hline Means (M) & 2.25 & 3.25 & 4.25 & 3.75 & 3.75 & 2.5 & 1 \\
\hline Feng \& English (1972) & 1.5 & 1 & 3 & 2 & 5 & 2 & 1 \\
\hline
\end{tabular}

From Table 1 we could see that the grammatical intricacy is the same across all translations, while the mean of lexical density of women translators is lower than that of men, except the fifth column, where our analysis focus is the "markedness" which has nothing to do with spoken and written style. Thus, we could say that versions of women translators are more spoken whereas men's translations are more written in style, embodied in:

(i) women translators are inclined to use more specific and concrete verbs or adjectives, while men tend to use more abstract nouns;

(ii) women translators are inclined to use more spoken vocabularies while men tend to use more written ones.

\subsection{Choice of Syntactic Patterns}

Translations of men and women translators may differ in the choice of syntactic patterns. For example:

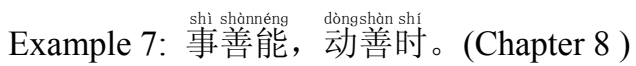

Chen (1989): Projects are carried out by good talents, activities are good in timing.

Guin (1997): The good of work is skill, and of action, timing.

Chen (2004): It adapts to all necessities./It moves at the right moment.

Feng \& English (1972): In daily life, be competent. /In action, be aware of the time and the season.

He et al. (1985): He is competent in deeds, /He is timely in action.

Wing (1986): The value in work is competence. The value in effort is timeliness.

Mair (1990): The quality of an enterprise depends on ability, the quality of movement depends on timing.

$\mathrm{Gu}$ (1995): He does a thing as properly as water,/He takes action as timely as water.

When translating the clause complex, all of the men translators use a parallel structure "he is ...in..., he is ...in..." "the value in..., the value in..." and "the quality of...depends on..., the quality of... depends on..." "he...as...as..., he...as...as..." which are consistent in form, and the choice of words like "value" and "quality" are abstract in nature. However, women translators adopt a casual style of sentence patterns without parallel constructions and abstract wordings, whereas Feng \& English's men-women cooperated translations lies in between, with somewhat parallel structure of "in...be..., in...be..." which is not so uniform compared with the men's translation but more consistent than women's, and with concrete wording.

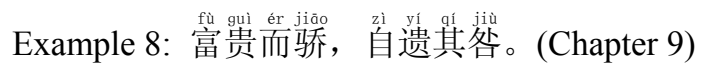

Chen (1989): To be rich, exalted, and proud, this is to invite blame upon oneself.

Guin (1997): Wealth, status, pride, are their own ruin

Chen (2004): Those who vaunt their position and worth risk attracting blame.

Feng \& English (1972): Claim wealth and titles, and disaster will follow. 
He et al. (1985): To be proud with honour and wealth will bring misfortune.

Wing (1986): Pride in wealth and position /Is overlooking one's collapse.

Mair (1990): If wealth and honor make you haughty, you bequeath misfortune upon yourself.

$\mathrm{Gu}$ (1995): When a man of wealth and rank is arrogant,/He is looking for a calamity upon himself

When translating this clause complex, women translators all use simple clause (Guin) or paratactic relations connected by "and" (Feng \& English, Chen (1989) and Chen (2004)), whereas men, except Wing (1986), adopt a complex clause with embedding (He et al.) and hypotactic relations with "if" and "when" as connectives (Mair and $\mathrm{Gu}$ ).

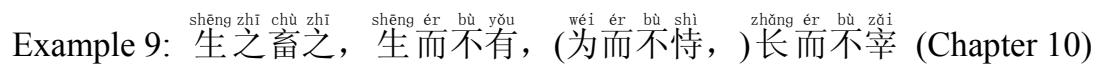

Chen (1989): To give birth yet not to claim possession (yu),/To act (wei) yet not to hold on to,/To grow (chang) yet not to lord over (tsai)

Guin (1997): To bear and not own, /to act and not lay claim, /to lead and not to rule

Chen (2004): Can one give life and grow life and yet claim no possession?/Can one supervise and benefit others, yet exercise no authority and rely on no pride?

Feng \& English (1972): Bearing yet not possessing, /Working yet not taking credit, /Leading yet not dominating

He et al. (1985): To beget all things, but not to take possession of them, /To advance them, /but not to take credit for doing so, /To be leader but not master of them

Wing (1986): Produce things, cultivate things; /Produce but do not possess. /Act without expectation. /Advance without dominating.

Mair (1990): It gives birth to them and nurtures them,/It gives birth to them but does not possess them,/It rears them but does not control them.

$\mathrm{Gu}$ (1995): Giving all things life and propagation/Without claiming to be their owner,/Benefiting them without claiming to be their benefactor, And being their head without ruling them

In re-individuating this clause complex, we can see that women translators (except Chen (2004)) employs a concise expression, omitting Participants and using only the Process, while men translators (except Wing (1986)) choose a complete expression with Participant and Process and sometimes even with Circumstance, like He et al.'s "To advance (Process) them (Participant), but not to take (Process) credit (Participant) for doing so (Circumstance)".

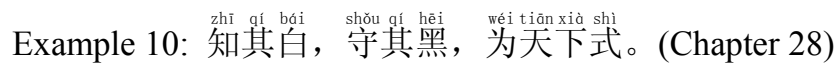

Chen (1989): To know (chih) the white (pe), /But to abide (shou) by the black (heh), /Is to be the model (shih) of the world.

Guin (1997): Knowing light, /and staying dark, /be a pattern to the world.

Chen (2004): Recognize the white - the yang,/guard the black - the yin./Be a model under Heaven.

Feng \& English (1972): Know the white,/But keep the black!/Be an example to the world!

He et al. (1985): He who knows the white (glory) but keeps to the black (obscure), is ready to be the (divination) instrument of under Heaven.

Wing (1986): Know the white, /Hold to the black; /Become the world's pattern.

Mair (1990): Know whiteness, /Maintain blackness, /and be a model for all under heaven.

$\mathrm{Gu}$ (1995): Though knowing what is honor, /You are ready to play the role of the disgraced/And content to be a valley in the world.

Similarly, for this example, women translators re-individuate this clause complex via a succinct approach and relatively simple syntactic structure, all adopt a "Process + Participant" structure (like "know the white" "staying dark"), while He et al.'s (1985) and Gu's (1995) translations are relatively complex in which the former involves an embeded clause complex (paratactic), and the latter consists both paratactic and hypotactic logical relations Table 2 and Table 3 show the logical relation of these two translations: 
Table 2. Logical relation of He et al.'s (1985) translation

\begin{tabular}{ccc}
\hline $\mathrm{He} \quad$ who knows the white (glory) & but keeps to the black (obscure), & $\begin{array}{c}\text { is ready to be the (divination) instrument of } \\
\text { under Heaven. }\end{array}$ \\
\hline 1 & +2 \\
\hline
\end{tabular}

Table 3. Logical relation of Gu's (1995) translation

\begin{tabular}{ccc} 
Though knowing what is honor, & $\begin{array}{c}\text { You are ready to play the role of the } \\
\text { disgraced, }\end{array}$ & And content to be a valley in the world. \\
\hline$\alpha$ & 1 & $\times \beta$ \\
\hline
\end{tabular}

Here we also use lexical density (LD) and grammatical intricacy (GI) as further evidence, see Table 4, where the means of LD of women's translations are all lower than that of the men's, whereas the means of GI of women's are all either equal to or higher than that of the men's. Therefore, men's translations are more written in style compared with the more spoken ones of women's, reflected in:

(i) women translators are inclined to use relatively simple structures, while men are more likely to use more complex structures;

(ii) women tend to use more succinct expressions by omitting unnecessary functional elements, while men are inclined to use more complete ones by involving Participant and Circumstance;

(iii) women are more likely to use casual expressions, while men tend to use more consistent or parallel patterns.

Table 4. lexical density and grammatical intricacy of the ST and each English versions for example 7-10

\begin{tabular}{|c|c|c|c|c|c|c|c|c|}
\hline & \multicolumn{2}{|c|}{$\begin{array}{l}\text { 事善能, } \\
\text { 动善时。 }\end{array}$} & \multicolumn{2}{|c|}{$\begin{array}{l}\text { 富贵而骄, } \\
\text { 自遗其处。 }\end{array}$} & \multicolumn{2}{|c|}{$\begin{array}{l}\text { 生之畜之, 生而不有, } \\
\text { (为而不恃, ) 长而不宰。 }\end{array}$} & \multicolumn{2}{|c|}{$\begin{array}{c}\text { 知其白, 守其黑, } \\
\text { 为天下式。 }\end{array}$} \\
\hline & LD & GI & LD & GI & LD & GI & LD & GI \\
\hline ST & 3 & 2 & 3 & 2 & 1 & 8 & 2 & 3 \\
\hline Chen (1989) & 3.5 & 2 & 1.5 & 4 & 1.33 & 6 & 2 & 3 \\
\hline Guin (1997) & 2.5 & 2 & 5 & 1 & 1.17 & 6 & 2 & 3 \\
\hline Chen (2004) & 2.5 & 2 & 3 & 2 & 1.86 & 7 & 2.67 & 3 \\
\hline Means (F) & 2.83 & 2 & 3.17 & 2.33 & 1.45 & 6.33 & 2.22 & 3 \\
\hline He et al. (1985) & 2 & 2 & 2.5 & 2 & 1.67 & 6 & 3.33 & 3 \\
\hline Wing (1986) & 3 & 2 & 5 & 1 & 1.83 & 6 & 2.33 & 3 \\
\hline Mair (1990) & 4 & 2 & 3.5 & 2 & 1.67 & 6 & 2 & 3 \\
\hline Gu (1995) & 4 & 2 & 3 & 2 & 1.83 & 6 & 3 & 3 \\
\hline Means (M) & 3.25 & 2 & 3.5 & 1.75 & 1.75 & 6 & 2.67 & 3 \\
\hline Feng \& English (1972) & 3.5 & 2 & 2.5 & 2 & 1.17 & 6 & 2 & 3 \\
\hline
\end{tabular}

\subsection{Choice of Mood}

Men and women translators may also differentiate each other in the choice of mood. For example:

Example 11: 故常光无欲, 以观其妙; 常常有欲, 以观其徽。(Chapter 1)

Chen (1989): Therefore, by the Everlasting (ch'ang) Non-Being (wu),/We desire (yü) to observe (kuan) its hidden mystery (miao);/By the Everlasting (ch'ang) Being (yu),/We desire (yü) to observe the manifestations (chiao).

Guin (1997): So the unwanting soul sees what's hidden, /and the ever-wanting soul sees only what it wants.

Chen (2004): Observe the mysteries of the Tao without longing./Survey its appearance with desire.

Feng \& English (1972): Ever desireless, one can see the mystery. /Ever desiring, one sees the manifestations.

He et al. (1985): Therefore, the subtleties of Tao are always apprehended through their formlessness, /The limits of things are always seen through their form. 
Wing (1986): Thus, without expectation/One will always perceive the subtlety;/And, with expectation/One will always perceive the boundary.

Mair (1990): Always be without desire in order to observe its wondrous subtleties;/Always have desire so that you may observe its manifestations.

Gu (1995): Hence one should gain an insight into the beginning of the Tao by constantly observing the Nothingness, And should perceive the end of the Tao by constantly observing the Being

Chen's (1989) re-individuation employs the first person plural "we", not only enacting the identity positioning of the translator, but also inviting the TL reader to a similar self-location, aligning with the reader. Guin (1997) chooses two opposite "unwanting soul" and "ever-wanting soul" as subjects to clearly and subjectively categorize people into two distinct groups, in which readers will consider which group they are probably in. In comparison, Feng \& English (1972) use indefinite pronoun "one" with more or less objective flavor and low value modal verb of probability "can", reflecting more gentle mood. Wing (1986) re-individuates also with "one" and median value modal verbs of probability "will", a little bit more affirmed than Feng \& English's translation. For Gu's re-individuation, he uses the indefinite pronoun "one", and the modal operator "should" manifesting strong obligation, which alienates the translator with the reader, getting a feeling of preaches. However, Chen (2004) and Mair (1990) select the imperative, which is relatively stronger in mood than the other declarative re-individuations, and the choice of "always" in Mair's (1900) translation made it a stronger mood than that of Chen's (2004). For He et al. (1985), he chooses passive voice, which seems more objective.

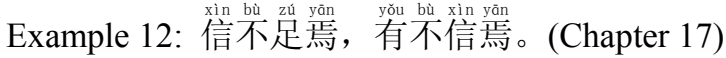

Chen (1989): When you don't trust (hsin)[the people] enough, /Then they are untrustworthy (puhsin).

Guin (1997): To give no trust is to get no trust.

Chen (2004): If they do not rule the country with faith, the people will not respond to them with trust.

Feng \& English (1972): Who does not trust enough will not be trusted.

He et al. (1985): Only when one is not faithworthy, will faithless events take place!

Wing (1986): Those who lack belief /Will not in turn be believed.

Mair (1990): When the ruler's trust is wanting, there will be no trust in him.

$\mathrm{Gu}$ (1995): The lack of faith on the part of the ruler, Leads to the lack of confidence in him on the part of the people.

Chen's (1989) re-individuation employs the second person "you", softening the mood, gaining a feeling that the translator attempts to have a dialogue with TL readers, which narrows the distance between the translator and the TL reader and thus aligns with the reader. Guin (1997) uses a non-finite clause, omitting the Subject and Finite in the MOOD system in the two embedded clauses "to give no trust" and "to get no trust", and omitting the Agent in Transitivity system, such omission makes the reference vague and involves the reader. Feng \& English (1972) and Wing (1986) choose "who" and "those who" as general reference, including readers; He et al. (1985) make a general reference by using indefinite pronoun "one", also including readers; Chen (2004) choose third person plural "they" and excludes readers; similarly, Mair's (1990) and Gu's (1995) re-individuation use the third person "the ruler", standing as an outsider so as to be more objective.

According to Example 11 and 12, we can find that Chen's (2004) re-individuation is closer to men's translations instead of women translators' in terms of mood, which is stronger and more objective. That might because she behaves more like men translators and writers in order to get things more easily published in the gender unequal society, where men are prior in most of the professions.

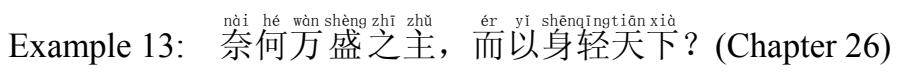

Chen (1989): How could the Lord of ten thousand chariots,/Conduct himself lightly in the world?

Guin (1997): How can a lord of ten thousand chariots let his own person weigh less in the balance than his land?

Chen (2004): Unfortunately the great ruler of ten thousand chariots governs the country indiscreetly.

Feng \& English (1972): Why should the lord of ten thousand chariots act lightly in public?

He et al. (1985): How is it that a lord of ten thousand chariots belittles his own importance under Heaven? 
Wing (1986): How can leaders with ten thousand chariots /Have a light-hearted position in the world?

Mair (1990): How then should a king with ten thousand chariots conduct himself lightly before all under heaven?

$\mathrm{Gu}$ (1995): Why should a ruler of ten thousand chariots/Take reckless action to govern the empire

Gorn-Old (1904): Alas that a king with many chariots should conduct himself with frivolity in the midst of his kingdom!

The ST is a Wh-interrogative in terms of the MOOD system. Chen (2004) re-individuates it into declarative, relatively weaker in mood than the ST, while Gorn-Old (1904) translated it into exclamative, relatively stronger in mood than the ST; the other 5 renditions all re-individuate the ST into Wh-interrogative which is consistent with the ST. For the choice of modal verbs, the sequence is "could (Chen 1989) $<$ can (Guin and Wing) $<$ should (Feng \& English and Mair)" from weak to strong. For the comparison of Feng \& English's and Mair's translation, Why-interrogative is stronger in mood than How-interrogative, and thus Mair $<$ Feng \& English. He et al. uses the emphatic pattern "How is it that...", strengthened mood in some extent. Therefore, the rendition order in terms of mood from weak to strong is: Chen (2004) < Chen (1989) < Guin (1997) = Wing (1986) < Mair $<$ Feng \& English (1972) < Gorn-Old (1904).

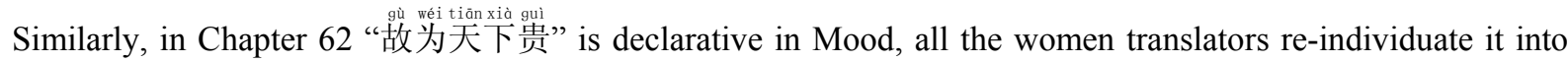
declarative, while Bynner (1944) and Bahm (1958), the two men translators re-individuate it into interrogative: Bynner uses Wh-interrogative "What men in all the world could have more wealth than they?", while Bahm uses polar-interrogative "Is this not the reason why it is the most worthwhile thing in the world?", both get strengthened in mood.

To sum up, men and women translators differ in mood selection:

(i) men tend to use stronger and stiffer tone than women, which unconsciously alienating the reader to some extend, while women are more likely to use more gentle tone and better at aligning readers.

(ii) men are more objective in the choice of the Subject and Modal operations, while women are more subjective.

\section{Conclusion}

Translator's gender, as one of the most important individual factors in both the hierarchy of individuation in SFL and also Translation Studies, has been explored in the English translations of the Tao Te Ching. Men and women translators differentiate themselves in three aspect: the choice of words, the choice of syntactic patterns and the choice of mood. The result shows that women translators' re-individuation are more spoken, while men are more likely to re-individuate in a more written style. Specific reflections are summarized in Table 5:

Table 5. Differences and embodiment in men and women translators

\begin{tabular}{lll}
\hline Choice of Words & Women: more spoken & Men: more written \\
\hline Choice of Syntax & use concrete verbs and adjectives & use abstract nouns \\
& use more spoken vocabularies & use more written vocabularies \\
\hline use relatively simple structures & use more complex structures \\
& use more succinct expressions by & use more complete ones by involving \\
& omitting unnecessary functional & Participant and Circumstance \\
elements, leaving only the Process & \\
use casual expressions & use more consistent patterns \\
\hline use more gentle tone & use stronger and stiffer tone \\
more subjective in the choice of the & more objective in the choice of the \\
& Subject and Modal operations & Subject and Modal operations
\end{tabular}

\section{References}

Bahm, A. J. (1958). Tao Teh King: By Lao Tzu, Interpreted as Nature and Intelligence. New York: E. Ungar.

Bernstein, B. (2000). Pedagogy, Symbolic Control and Identity: Theory, Research, Critique. London: Taylor \& Francis. 
Bynner, W. (1944). The Way of Life According to Laotzu. New York: Perigree.

Chen, C. H. (2004). Tao te ching cards : Lao Tzu's classic Taoist text in 81 cards. New York: Marlowe.

Chen, E. M. (1989). The Tao Te Ching. New York: Paragon House.

Chen, L.O. (2000). Tao Te Ching. New York: iUniverse.

Feng, G. F., \& English, J. (1972). Tao Te Ching. New York: Vintage Books.

Gorn-Old, W. (1904). The Simple Way: Lao Tzu (The 'Old Boy'). London: Philip Wellby.

Gu, Z. K. (1995). Lao Zi: The Book of Tao and Teh. Beijing: Peking University Press.

Guin, U. K. L. (1997). Lao Tzu Tao Te Ching. Boston \& London: Shambhala.

Halliday, M. A. K. (1964). Comparison and translation. In M. A. K. Halliday, A. McIntosh, \& P. D. Strevens (Eds.), The Linguistic Sciences and Language Teaching. London: Longmans.

Halliday, M. A. K. (1985). Spoken and Written Language. Victoria, Australia: Deakin University.

He, G. H. et al. (1993). The Book of Lao Zi. Beijing: Foreign Languages Press.

Mair, V. H. (1990). Tao Te Ching. New York: Bantam Books.

Martin, J. R. (1992). English Text: System and Structure. Amsterdam: Benjamins. http://dx.doi.org/10.1075/z.59

Martin, J. R. (2006). Genre, ideology and intertextuality: A systemic functional perspective. [Special issue]. Linguistics and the Human Sciences, (2), 275-298.

Martin, J. R. (2008a). Tenderness: Realisation and instantiation in a Botswanan town. In N. Norgaard (Ed.), Systemic functional linguistics in use (pp. 30-62). Odense: Odense Working Papers in Language and Communication.

Martin, J. R. (2008b). Innocence: realisation, instantiation and individuation in a Botswanan town. In N. Knight \& A. Mahboob (Eds.), Questioning linguistics (pp. 27-54). Newcastle: Cambridge Scholars Publishing.

Martin, J. R. (2009). Realisation, instantiation and individuation: Some thoughts on identity in youth justice conferencing [Special issue]. DELTA, (25), 549-583. http://dx.doi.org/10.1590/S0102-44502009000300002

Martin, J. R., \& Wang, Z. H. (2008). Realisation, instantiation and individuation: A systemic-functional linguistic perspective. Journal of Shanghai Jiaotong University (Philosophy and Social Sciences Edition), (5), 73-81.

Matthiessen, C. M. I. M. (2003). Language, social life and discursive maps. Plenary for Australian Systemic Functional Linguistics Conference, Adelaide.

Matthiessen, C. M. I. M. (2007). The "architecture" of language according to systemic functional theory. In R. Hasan, C. M. I. M. Matthiessen, \& J. Webster (Eds.), Continuing Discourse on Language (vol. 2, pp. 505-562). London, Oakville: Equinox.

Wang, X., \& Yang, B. J. (2015). Translation from the perspective of individuation in systemic functional linguistics: A case study of English translation of Tao Te Ching. Translation Quarterly, (77), forthcoming.

Wang, Z. H. (2011). Introduction. In Z. H. Wang (Ed.), Collective Works of J. R. Martin (8): Forensic Linguistics. Shanghai: Shanghai Jiaotong University Press.

Wing, R. L. (1986). The Tao of Power. Garden City, New York: Doubleday.

Xin, H. J. (2011). Interpretation of Tao-te-ching: A feminism. Foreign Languages in China, (2), 93-97.

Zheng, Y. J. (2011). Translator's gender and language analysis of Laozi's English translation. Special Issues in the 6th Social Science Seminar in Taipei No. 1 Girls' High School.

\section{Copyrights}

Copyright for this article is retained by the author(s), with first publication rights granted to the journal.

This is an open-access article distributed under the terms and conditions of the Creative Commons Attribution license (http://creativecommons.org/licenses/by/3.0/). 